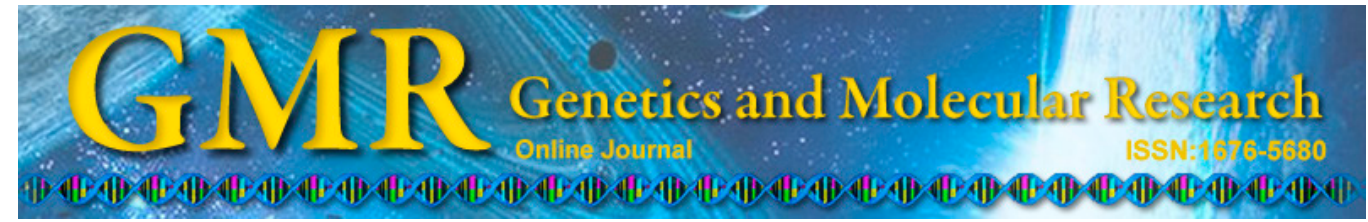

\title{
Endophytic bacteria from Piper tuberculatum Jacq.: isolation, molecular characterization, and in vitro screening for the control of Fusarium solani f. sp piperis, the causal agent of root rot disease in black pepper (Piper nigrum L.)
}

\author{
S.B. Nascimento ${ }^{1}$, A.M. Lima ${ }^{1,2,3}$, B.N. Borges ${ }^{4}$ and C.R.B. de Souza ${ }^{1}$ \\ ${ }^{1}$ Instituto de Ciências Biológicas, Universidade Federal do Pará, \\ Belém, PA, Brasil \\ ${ }^{2}$ Programa de Pós-Graduação em Genética e Biologia Molecular, \\ Belém, PA, Brasil \\ ${ }^{3}$ Programa de Pós-Graduação em Agronomia, \\ Universidade Federal Rural da Amazônia, Belém, PA, Brasil \\ ${ }^{4}$ Instituto Socioambiental e dos Recursos Hídricos, \\ Universidade Federal do Pará, Belém, PA, Brasil
}

Corresponding author: C.R.B. de Souza

E-mail: bsouza@ufpa.br

Genet. Mol. Res. 14 (3): 7567-7577 (2015)

Received April 1, 2015

Accepted May 26, 2015

Published July 3, 2015

DOI http://dx.doi.org/10.4238/2015.July.3.32

ABSTRACT. Endophytic bacteria have been found to colonize
internal tissues in many different plants, where they can have several
beneficial effects, including defense against pathogens. In this study,
we aimed to identify endophytic bacteria associated with roots of
the tropical piperaceae Piper tuberculatum, which is known for its 
resistance to infection by Fusarium solani f. sp piperis, the causal agent of black pepper (Piper nigrum) root rot disease in the Amazon region. Based on 16S rRNA gene sequence analysis, we isolated endophytes belonging to 13 genera: Bacillus, Paenibacillus, Pseudomonas, Enterobacter, Rhizobium, Sinorhizobium, Agrobacterium, Ralstonia, Serratia, Cupriavidus, Mitsuaria, Pantoea, and Staphylococcus. The results showed that $56.52 \%$ of isolates were associated with the phylum Proteobacteria, which comprised $\alpha, \beta$, and $\gamma$ classes. Other bacteria were related to the phylum Firmicutes, including Bacillus, which was the most abundant genus among all isolates. Antagonistic assays revealed that Pt12 and Pt13 isolates, identified as Pseudomonas putida and Pseudomonas sp, respectively, were able to inhibit $F$. solani f. sp piperis growth in vitro. We describe, for the first time, the molecular identification of 23 endophytic bacteria from P. tuberculatum, among which two Pseudomonas species have the potential to control the pathogen responsible for root rot disease in black pepper in the Amazon region.

Key words: Black pepper; 16S rRNA gene; Fusarium solani f. sp piperis; Piper tuberculatum; Pseudomonas; Root rot disease

\section{INTRODUCTION}

Endophytic bacteria have been found to colonize the internal tissues of every plant studied. Unlike phytopathogens, endophytic bacteria do not cause visible harm to the host; in contrast, they can exert several beneficial effects on the plant, including defense against pathogens and increased growth and development through the production of plant growthpromoting substances and/or by fixing nitrogen from the atmosphere (Glick, 2012; MercadoBlanco and Lugtenberg, 2014). Endophytic bacteria can control plant diseases via antagonistic mechanisms, including competition, antibiosis, parasitism, and cross-protection, which result in induced systemic resistance (ISR) (Silo-Suh et al., 1994; van Loon et al., 1998; Verhagen et al., 2010).

The study of endophytes is important to understand their ecological role in nature, and for the identification of new microorganisms that have potential biotechnological applications (Mercado-Blanco and Lugtenberg, 2014). In addition, molecular biology techniques based on polymerase chain reaction (PCR) amplification, including use of the 16S rRNA sequence, have contributed to the precise identification of endophytic bacterial communities (Cho et al., 2007; Kang et al., 2007).

Endophytic bacteria have been isolated from many plant species, such as citrus (Trivedi et al., 2011), coffee (Vega et al., 2005), ginseng (Cho et al., 2007), sugarcane (Hassan et al., 2011), coleus (Vanitha and Ramjegathesh, 2014), and black pepper (Benchimol et al., 2000).

Black pepper (Piper nigrum L.) is one of the most widely used spices in the world. The Piperaceae family comprises about 1400 species (Soltis et al., 1999) distributed mainly in the American tropics and Southern Asia, from where black pepper originated (Jaramillo and Manos, 2001). Studies aiming to isolate endophytic bacteria that have the potential to control diseases of black pepper have been reported. For example, Benchimol et al. (2000) identified a Methylobacterium radiotolerans bacterium, which reduced mortality of black pepper seed- 
lings caused by root rot disease. Antagonistic bacteria for the biological control of nursery wilt in black pepper were isolated by Anith et al. (2003). In addition, Aravind et al. (2009) isolated Bacillus and Pseudomonas bacteria that are effective in the biological control of Phytophthora capsici, the causal agent of the black pepper foot rot disease in India and other Asian countries.

Although significant advances have been made in the identification of endophytic bacteria of black pepper, little is known about endophytes of Piperaceae from the American tropics. Among them, Piper tuberculatum Jacq. is known for its resistance to infection by Fusarium solani f. sp piperis (Albuquerque et al., 2001), which is the causal agent of rot root disease in black pepper, and leads to root rot, leaf fall, and plant death (Albuquerque and Ferraz, 1976).

Pará State, in the Amazon region, is the main Brazilian producer of black pepper; however, its production has been affected by root rot disease (IBGE, 2014). This crop was introduced in Brazil in the 17th century and is currently of significant social and economic importance in the Amazon region, where the pathogen F. solani $\mathrm{f}$. sp piperis is endemic. Since susceptibility to root rot disease was found in the germplasm collection of all 35 black pepper cultivars available in Brazil (Albuquerque et al., 2001), Piper species native to the Amazon region, including $P$. tuberculatum, comprise an important source of resistance to infection, for use in disease control.

Therefore, in this study, we aimed to identify endophytic bacteria of $P$. tuberculatum with the potential to control $F$. solani f. sp piperis. Endophytic bacteria isolated from $P$. $t u$ berculatum roots were identified using $16 \mathrm{~S}$ rRNA gene sequencing, and their ability to inhibit fungal growth was evaluated.

\section{MATERIAL AND METHODS}

\section{Plant material and isolation of root-associated bacteria}

Healthy P. tuberculatum plants were harvested from a secondary forest (Ananindeua, Pará, Brazil). Roots were washed in running tap water to eliminate soil residue and other particles. Next, the root surface was disinfected with $70 \%$ ethanol (v/v) for $1 \mathrm{~min}, 2 \%$ sodium hypochlorite (v/v) for $6 \mathrm{~min}$, followed by five rinses in sterile distilled water. The efficiency of the disinfection process was checked by plating aliquots of the sterile distilled water used in the final rinse onto nutrient agar (NA) and tryptic soy agar (TSA) media (both supplied by Difco, USA), containing Benomyl $(50 \mathrm{mg} / \mathrm{mL})$ to inhibit fungal growth. Plates were incubated at $28^{\circ} \mathrm{C}$ for 7 days. To eliminate external contamination of roots, their tips were excised using sterile razor blades. Next, disinfected roots were macerated by a pestle in sterile phosphate-buffered saline (PBS 1X: $137 \mathrm{mM} \mathrm{NaCl}, 10 \mathrm{mM} \mathrm{Na} \mathrm{HPO}_{2}, 1.8 \mathrm{mM} \mathrm{KH}_{2} \mathrm{PO}_{4}, 2.7 \mathrm{mM} \mathrm{KCl}, \mathrm{pH} 7.4$ ), followed by incubation at $28^{\circ} \mathrm{C}$ for $1 \mathrm{~h}$ under agitation $(150 \mathrm{rpm})$. Serial dilutions of the bacterial suspension were plated onto both NA and TSA, containing Benomyl $(50 \mathrm{mg} / \mathrm{mL})$ and the plates were incubated at $28^{\circ} \mathrm{C}$. Bacterial growth was initially assessed after $48 \mathrm{~h}$ and extended for until seven days of incubation. Single colonies were isolated and grouped based on growth rate and phenotypic characteristics, such as colony morphology, color, opacity, and size.

\section{Isolation of DNA from endophytic bacteria}

Isolated endophytic bacteria were cultured and collected by centrifugation at 13,000 $g$ for $1 \mathrm{~min}$. Cell pellets were resuspended in TE buffer $(50 \mathrm{mM} \mathrm{NaCl}, 10 \mathrm{mM}$ Tris HCl, 50 
mM EDTA, $\mathrm{pH}$ 8.0), and boiled for 5 min to induce cell lysis. After the addition of RNase and SDS solutions, cell extracts were incubated at $65^{\circ} \mathrm{C}$ for $30-60 \mathrm{~min}$. The DNA-containing solution was extracted twice with phenol-chloroform-isoamyl alcohol and twice with chloroform-isoamyl alcohol, followed by alcohol-precipitation from the aqueous phase. DNA was collected by centrifugation at 13,000 $\mathrm{g}$ for $20 \mathrm{~min}$, dissolved in ultra-pure sterile water, and stored at $-20^{\circ} \mathrm{C}$.

\section{Amplification of the 16 rRNA gene and sequence analysis}

To amplify the 16S rRNA gene, a pair of PCR primers, Y1F (5'-TGGCTCAGAACG AACGCTGGCGGC-3') and Y3R (5'-TACCTTGTTACGACTTCACCCCAGTC-3') (Cruz et al., 2001), was used. The PCR assay conditions were as follows: initial denaturation at $94^{\circ} \mathrm{C}$ for $5 \mathrm{~min}$, followed by 30 cycles of $94^{\circ} \mathrm{C}$ for $1 \mathrm{~min}, 55^{\circ} \mathrm{C}$ for $1 \mathrm{~min}$, and $72^{\circ} \mathrm{C}$ for $2 \mathrm{~min}$, and final extension at $72^{\circ} \mathrm{C}$ for $20 \mathrm{~min}$. PCR products were cloned into the pGEM-T Easy vector (Promega, USA) and sequenced using the Big Dye Terminator kit (Applied Systems, USA). Nucleotide sequences were compared to a database using the BLAST program from the NCBI (Altschul et al., 1990). Phylogenetic analysis was performed using the computer software Mega v. 5.04 (Tamura et al., 2011) using the neighbor-joining method. In order to evaluate the stability of nodes, we performed bootstrap analysis with 1000 replicates.

\section{Inhibition of $\boldsymbol{F}$. solani f. sp piperis growth}

Endophytic bacteria were tested for their ability to inhibit $F$. solani $\mathrm{f}$. sp piperis growth using plates containing potato-dextrose-agar (PDA) medium. A $0.8-\mathrm{cm}$ diameter mycelium disc was placed at the center of a PDA plate and bacterial colonies were streaked $1 \mathrm{~cm}$ from the borders of the plate. As a negative control, PDA plates containing mycelium disc with no bacteria were used. There were five repetitions per treatment. Plates were incubated at $28^{\circ} \mathrm{C}$ for 12 days. Anti-fungal activity was estimated by measuring radial growth inhibition of $F$. solani $\mathrm{f}$. sp piperis. To determine differences in radial growth between samples and controls, statistical analyzes were performed using Tukey's test for comparison of means. Relative inhibition (RI) was calculated on the basis of growth in control plates as:

$$
\text { RI }(\%)=\frac{\text { Radial growth in control }- \text { Radial growth in samples }}{\text { Radial growth in control }} 100
$$

\section{RESULTS AND DISCUSSION}

\section{Isolation of endophytic bacteria associated with $P$. tuberculatum roots}

In this study, we aimed to identify endophytic bacteria associated with the roots of $P$. tuberculatum that have potential to control F. solani $\mathrm{f}$. sp piperis, which causes root rot disease of black pepper in the Amazon region, and leads to severe loss in crop production, and consequently affects the Brazilian economy.

To eliminate contamination by non-endophytic bacteria, the roots were surface-sterilized and the efficiency of the sterilization process was confirmed by the absence of bacterial growth on NA and TSA plates containing aliquots of the sterile distilled water that was used 
for the final rinsing of roots. Bacteria colonies grown on NA and TSA plates were first selected based on their morphological characteristics and growth rate. Some bacteria were observed after $48 \mathrm{~h}$ of incubation at $28^{\circ} \mathrm{C}$, while others exhibited extremely slow growth and were detected only after one week of culture. We isolated 28 morphologically distinct colonies.

Genomic DNA was extracted from these colonies and the 16S rRNA gene was amplified and sequenced. Next, amplified fragments were used to perform a comparative sequence analysis with sequences available in GenBank using the BLASTN program from the NCBI. Our results identified bacteria belonging to Bacillus, Paenibacillus, Pseudomonas, Enterobacter, Rhizobium, Sinorhizobium, Agrobacterium, Ralstonia, Serratia, Cupriavidus, Mitsuaria, Pantoea, and Staphylococcus genera. The 16S rRNA gene sequences of 23 P. tuberculatum endophytic bacteria were registered in the GenBank databases under the accession No.: JF900600-JF900622.

As shown in Table 1, the identity between the 16S rRNA gene sequences obtained here and those available in GenBank ranged from 94 to $99 \%$. Our results revealed that 23 endophytic bacteria belonging to 13 genera were isolated from $P$. tuberculatum grown in the Amazon region, where a high diversity of plant-associated microorganisms is expected. Many species of endophytic bacteria can be isolated from a single plant, and many factors, such as soil condition, phytopathogen population (Granér et al., 2003), plant age (Islam et al., 2010), host genotype, and plant variety can contribute to significant differences in endophytic bacterial diversity (Adams and Kloepper, 2002). In this context, studies have revealed various numbers of endophytic bacteria species in diverse plants. For example, 63 different endophytic isolates belonging to 13 different bacterial genera were isolated from ginseng roots (Cho et al., 2007); while 87 endophytic bacteria isolates from 19 genera were obtained from coffee plants collected in Colombia and Mexico (Vega et al., 2005). Therefore, the diversity of endophytic bacteria associated with $P$. tuberculatum roots observed in the present study is consistent with that reported in other crops.

Table 1. 16S rRNA gene sequence similarities of endophytic bacteria of Piper tuberculatum and sequences available in GenBank. Endophytic bacteria were isolated from roots and cultured on TSA and NA plates.

\begin{tabular}{|c|c|c|c|c|}
\hline Isolates & Medium & 16S rRNA gene (bp) & Best match in GenBank Database & Sequence identity $(\%)$ \\
\hline Pt1 (JF900600) & TSA & 1398 & Bacillus sp strain TZQ22 (HQ143630.1) & 99 \\
\hline Pt2 (JF900601) & TSA & 1411 & Bacillus sp strain SuP1 (EU912461.1) & 94 \\
\hline Pt3 (JF900602) & TSA & 1410 & Bacillus cereus strain S72 (FJ763650.1) & 99 \\
\hline Pt4 (JF900603) & NA & 1402 & Bacillus niacini strain BIHB 356 (FJ859698.2) & 99 \\
\hline Pt5 (JF900604) & NA & 1369 & Bacillus acidiceler strain CBD 119 (DQ374637.1) & 98 \\
\hline Pt6 (JF900605) & NA & 1401 & Bacillus megaterium strain E5 (JF416939.1) & 99 \\
\hline Pt7 (JF900606) & NA & 1223 & Bacillus cereus strain R10 (FR749846.1) & 97 \\
\hline Pt8 (JF900607) & TSA & 1379 & Paenibacillus sp strain TDSAS2-39 (GQ284529.1) & 99 \\
\hline Pt9 (JF900608) & TSA & 1391 & Paenibacillus sp strain TSWCW18 (GQ284463.1) & 99 \\
\hline Pt10 (JF900609) & NA & 1398 & Staphylococcus epidermidis strain BQN1R-01d (FJ380968.1) & 99 \\
\hline Pt11 (JF900610) & TSA & 1362 & Pseudomonas putida strain WAB1949 (AM184288.1) & 99 \\
\hline Pt12 (JF900611) & TSA & 1323 & Pseudomonas putida strain BJ10 (HQ848377.1) & 99 \\
\hline Pt13 (JF900612) & TSA & 1404 & Pseudomonas sp strain TA12-C (HM219617.1) & 99 \\
\hline Pt14 (JF900613) & NA & 1382 & Pantoea agglomerans strain SZ009 (EU596536.1) & 98 \\
\hline Pt15 (JF900614) & TSA & 1309 & Enterobacter sp strain BBTR105 (EF471230.1) & 99 \\
\hline Pt16 (JF900615) & NA & 1404 & Serratia marcescens strain HL1 (EU371058.1) & 99 \\
\hline Pt17 (JF900616) & NA & 1346 & Rhizobium lusitanum strain CCBAU 15087 (GU552881.1) & 99 \\
\hline Pt18 (JF900617) & NA & 1330 & Rhizobium lusitanum strain BLN7 (GQ181047.1) & 99 \\
\hline Pt19 (JF900618) & NA & 1329 & Agrobacterium rhizogenes strain CAF448 (FJ405385.1) & 99 \\
\hline Pt20 (JF900619) & NA & 1338 & Sinorhizobium sp strain 2-1 (HM151907.1) & 99 \\
\hline Pt21 (JF900620) & NA & 1319 & Ralstonia sp strain SK1 (DQ026295.1) & 99 \\
\hline Pt22 (JF900621) & NA & 1370 & Mitsuaria chitosanitabida strain IAM 14711T (AM501442.1) & 99 \\
\hline Pt23 (JF900622) & NA & 1371 & Cupriavidus pauculus strain KPS201 (AM418462.1) & 99 \\
\hline
\end{tabular}


Among the endophytes identified in the present study, 14 bacteria were isolated on NA plates, and nine were isolated on TSA plates (Table 1). The genus Bacillus was isolated from NA and TSA media, while Pseudomonas, Paenibacillus, and Enterobacter were restricted to TSA medium. Bacteria growing only on NA medium were Rhizobium, Sinorhizobium, Agrobacterium, Ralstonia, Serratia, Cupriavidus, Mitsuaria, Pantoea, and Staphylococcus. Therefore, the highest number of bacterial genera was found when NA medium was used. Several studies have used different culture media for the successful isolation of endophytic bacteria. For example, Trivedi et al. (2011) reported that NA medium can be used to isolate several citrus root endophytes that had potential to enhance plant growth and suppress disease. Likewise, TSA medium was efficient in isolating many endophytic bacteria from pepper, such as Pantoea, Pseudomonas, and Ralstonia (Kang et al., 2007). In conclusion, although there are data in the literature that demonstrate the efficiency of different media in the isolation of endophytic bacteria, the use of separate plates containing NA or TSA media was advantageous in the present study as it facilitated isolation of diverse species of $P$. tuberculatum endophytic bacteria.

\section{Endophytic bacteria of $P$. tuberculatum are associated with Proteobacteria and Firmicutes phyla}

A phylogenetic analysis was performed using the 16S rRNA gene sequences obtained in this study and those available in GenBank (Table 1). Our results revealed that endophytic bacteria are associated with the phyla Proteobacteria and Firmicutes (Figure 1).

Thirteen isolates $(56.52 \%$ of total) were associated with the phylum Proteobacteria, which comprised $\alpha, \beta$, and $\gamma$ classes with four, three, and six bacteria, respectively. Bacteria related to the $\gamma$-Proteobacteria class included Pseudomonas putida (Pt11 and Pt12), Pseudomonas sp (Pt13), Pantoea agglomerans (Pt14), Enterobacter sp (Pt15), and Serratia marcescens (Pt16). Pseudomonas is a well-known plant-associated bacterium found in the majority of plant species. These bacteria have been effective in the biological control of diverse diseases, such as foot rot in black pepper (Aravind et al., 2009) and grapevine gray mold caused by Botrytis cinerea (Verhagen et al., 2010). Additionally, Pseudomonas bacteria are considered plant growth-promoting bacteria (PGPB) due to many traits, which contribute to the growth and development of plants, such as the production of phytohormones and siderophores (Glick, 2012). Serratia marcescens and Pantoea agglomerans are also PGPB, since they can control plant disease (Hsieh et al., 2005) and promote plant growth (Selvakumar et al., 2007), cause solubilization of phosphates (Tripura et al., 2007), and cold tolerance (Selvakumar et al., 2007). We also identified four potential PGPB (Pt17, 18, 19, and 20) that are associated with the $\alpha$-Proteobacteria class. These four isolates were associated with the bacteria Rhizobium lusitanum, Agrobacterium rhizogenes, and Sinorhizobium sp, which are known to contribute to plant growth and development by fixing atmospheric $\mathrm{N}_{2}$ (Kanvinde and Sastry, 1990; Valverde et al., 2006; Talebi et al., 2008). Endophytic bacteria related to the $\beta$-proteobacteria class included the Pt21, 22, and 23 isolates. The bacterium Ralstonia has been found as PGPB in many crops, such as pepper (Kang et al., 2007). Hence, based on the literature, we can conclude that most isolated Proteobacteria that are associated with P. tuberculatum have the potential to contribute to defense against pathogens and/or the promotion of plant growth and development.

Endophytic bacteria affiliated with the phylum Firmicutes comprised $43.48 \%$ of the total isolates, and included the genera Bacillus, Paenibacillus, and Staphylococcus. Bacillus was the most abundant genus found and comprised seven isolates: $B$. sp (Pt1 and Pt2), B. ce- 


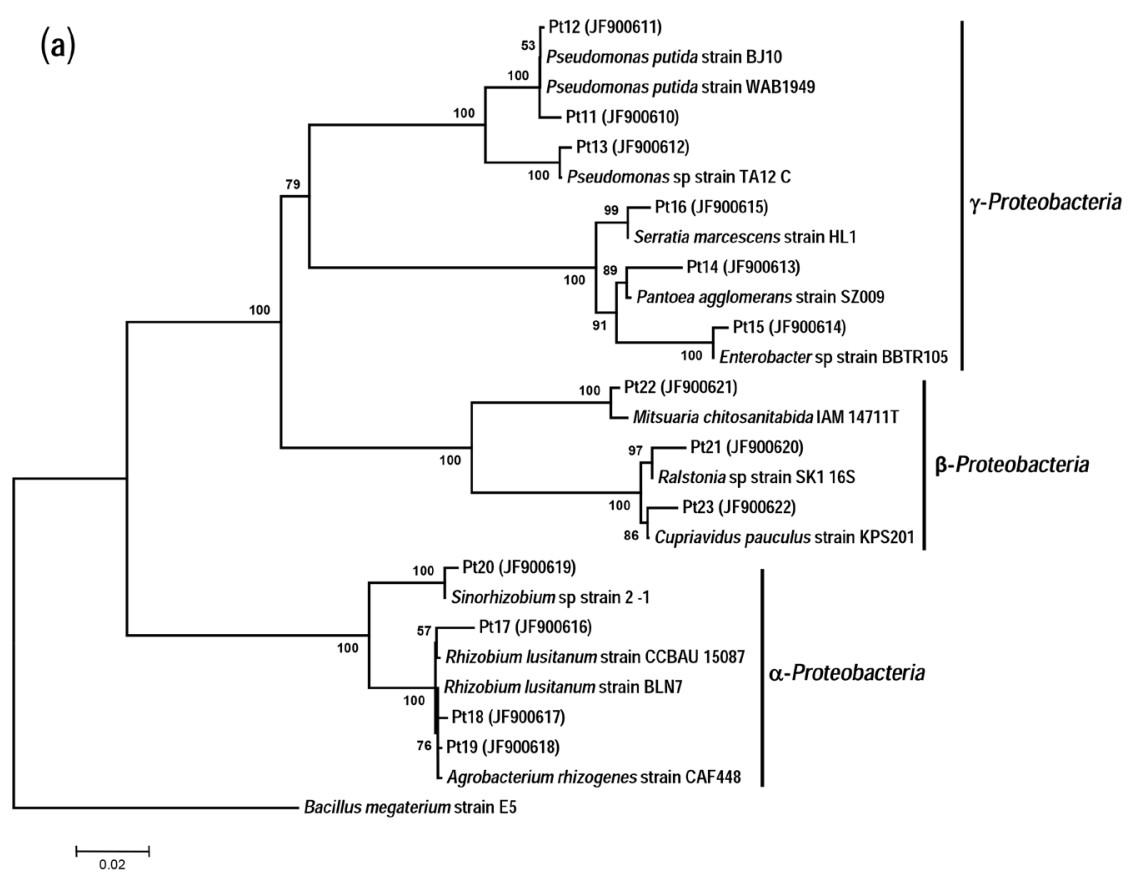

(b)

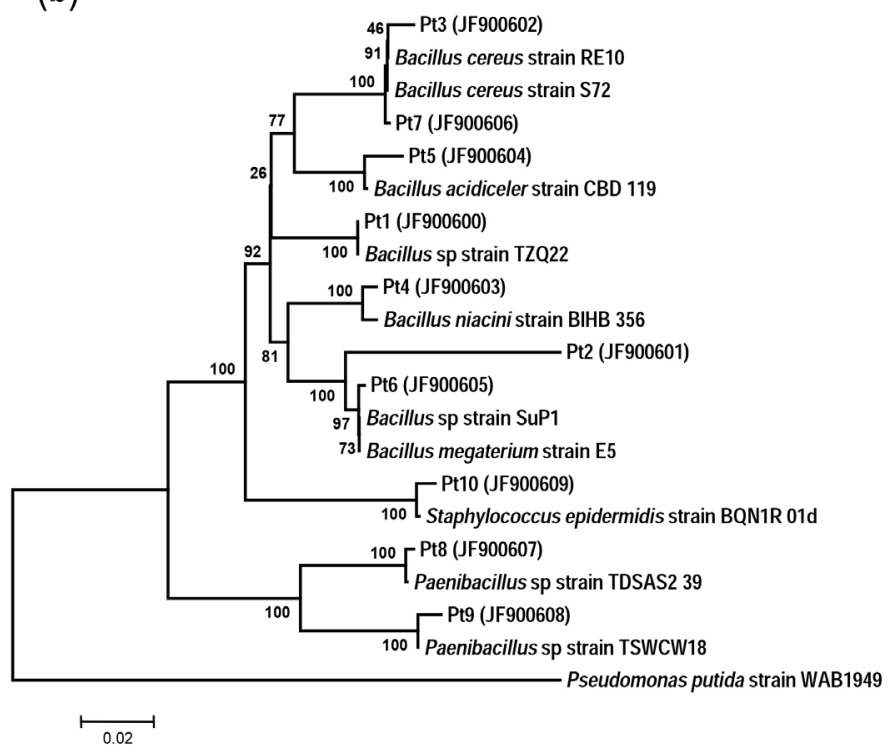

Figure 1. 16S rDNA-based dendrogram showing the phylogenetic relationship of endophytic bacteria from Piper tuberculatum roots and sequences available in GenBank Database cited in Table 1. Phylogenetic analysis was performed using the software Mega v. 5.04 and neighbor-joining method. The scale bar represents a $\%$ estimated difference in nucleotide sequence. Numbers above each node indicate bootstrap values. Sequences of Bacillus megaterium strain E5 (JF416939.1) and Pseudomonas putida strain WAB1949 (AM184288.1) were used as outgroup references for Proteobacteria (a) and Firmicutes (b) phyla, respectively. 
reus (Pt3 and $\mathrm{Pt} 7)$, B. niacini (Pt4), B. acidiceler (Pt5), and B. megaterium (Pt6). The $\mathrm{Pt} 8$ and Pt9 isolates matched those of Paenibacillus. Paenibacillus and Bacillus are known to protect plants against phytopathogenic fungi using different mechanisms, including chitinolytic activity (Huang et al., 2005; Singh et al., 2009) and via the production of fungistatic antibiotics (Silo-Suh et al., 1994). Therefore, among endophytic bacteria that were associated with the phylum Firmicutes isolated in this study, Bacillus and Paenibacillus are candidates that might be involved in the protection of $P$. tuberculatum against pathogens.

\section{Pseudomonas bacteria can inhibit in vitro growth of $F$. solani f. sp piperis}

We performed antagonistic assays to screen $P$. tuberculatum endophytic bacteria for the ability to inhibit F. solani f. sp piperis growth. For these assays, we used Pt1 to Pt16 isolates, except Pt10, identified as $S$. epidermidis, which is part of the normal human flora (Fey and Olson, 2010). These 15 isolates were selected for use in antagonistic assays because they shared the 16S rRNA sequence identity with bacteria that have known roles in the biological control of phytopathogens.

Our results revealed that Pt12 and Pt13 isolates, identified as $P$. putida and $P$. sp, respectively, were able to inhibit radial growth of $F$. solani $\mathrm{f}$. sp piperis on PDA medium, when compared to the negative control, i.e., without endophytic bacteria (Figure 2). A similar result was obtained when we compared these two isolates with the Pt3 isolate, identified as $B$. cereus, which showed no inhibition of fungal growth (Figure 2). Statistical analysis using Tukey's test revealed inhibition of fungal growth at $38.96 \%$ and $55.31 \%$ by Pt12 and Pt13 isolates, respectively (Table 2). These results are in accordance with those obtained in other studies, including a recent report by Vanitha and Ramjegathesh (2014), in which the inhibitory activity of Pseudomonas strains isolated from coleus rhizosphere against the fungus Macrophomina phaseolina ranged from 30 to $60 \%$. In addition, studies have reported the effective use of Pseudomonas bacteria, including P. putida strains, in the biological control of pathogens of several plants, such as cotton (Chen et al., 1995), black pepper (Tran et al., 2008), sugarcane (Hassan et al., 2011), and coleus (Vanitha and Ramjegathesh, 2014).

Although it was not the goal of the present study to elucidate the mechanisms by which Pt12 and Pt13 isolates were able to inhibit fungal growth, based on the literature, some hypotheses can be considered. For example, studies have shown that the mechanisms of Pseudomonas bacterial action in the control of phytopathogens include production of biosurfactant compounds (Tran et al., 2008) and the antibiotic pyoluteorin (Hassan et al., 2011). Another mechanism by which Pseudomonas bacteria can protect plants against pathogens is via the ISR (Kang et al., 2007; Verhagen et al., 2010), where plants inoculated with endophytic bacteria, followed by contact with pathogens, showed enhanced expression of genes involved in the ISR, indicating that these genes were primed to respond more intensely to pathogen attack. Changes frequently observed in plants during the ISR include structural changes in cell walls, enhanced activity of enzymes related to defense, and enhanced phytoalexin accumulation (van Loon et al., 1998; Liu et al., 2007; Verhagen et al., 2010). Interestingly, a recent study by Schenk et al. (2014) showed that $N$-acyl-homoserine lactone, a bacterial quorum-sensing molecule, was able to prime cell wall-related genes in Arabidopsis thaliana plants and, as a result, induce resistance to bacterial pathogens by way of cell wall reinforcement. Since we have identified sequences of $P$. tuberculatum that code for proteins potentially involved in the formation of structural barriers against $F$. solani $\mathrm{f}$. sp piperis infection, including a putative 
cell wall hydroxyproline-rich glycoprotein (Nascimento et al., 2009); it is possible that the Pseudomonas bacteria isolated in the present study contribute to resistance to this fungus by similar mechanisms. However, further studies will elucidate the roles of Pt12 and Pt13 isolates in the physiology of $P$. tuberculatum.

To the best of our knowledge, this study is the first report on the molecular identification of 23 endophytic bacteria from tropical P. tuberculatum, among which, two Pseudomonas bacteria were isolated that have the potential to control the pathogen responsible for root rot disease of black pepper in the Amazon region.

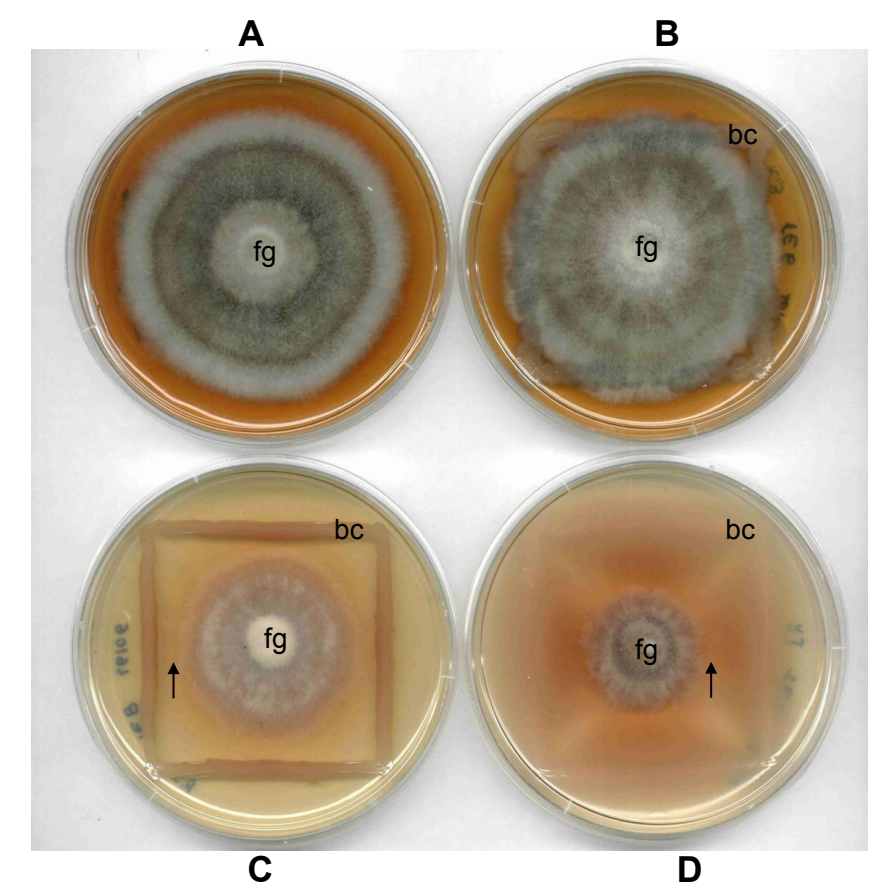

Figure 2. Assays of inhibition of Fusarium solani f. sp piperis growth by endophytic bacteria associated with roots of Piper tuberculatum on PDA medium at 12 days after incubation. A. F. solani f. sp piperis (control), B. F. solani f. sp piperis $+\mathrm{Pt} 3$ isolate (B. cereus), C. F. solani f. sp piperis $+\mathrm{Pt} 12$ isolate (P. putida) and D. F. solani f. sp piperis + Pt13 isolate $(P . \mathrm{sp})$. bc: bacterium, fg: fungus. The arrows point to the free zones.

Table 2. Inhibition of Fusarium solani f. sp piperis growth by endophytic bacteria associated with roots of Piper tuberculatum.

\begin{tabular}{|c|c|c|}
\hline Treatments & Radial growth $(\mathrm{cm})^{*}$ & Relative inhibition-RI (\%) \\
\hline F. solani f. sp piperis (control) & $7.34^{\mathrm{a}}$ & 0.00 \\
\hline F. solani $\mathrm{f}$. sp piperis $+\mathrm{Pt} 3$ isolate $($ B. cereus $)$ & $7.32^{\mathrm{a}}$ & 0.27 \\
\hline F. solani f. sp piperis + Pt12 isolate $(P$. putida $)$ & $4.48^{\mathrm{b}}$ & 38.96 \\
\hline F. solani f. sp piperis $+\mathrm{Pt} 13$ isolate $(P . \mathrm{sp})$ & $3.28^{\mathrm{c}}$ & 55.31 \\
\hline
\end{tabular}

*Means followed by different letters within one column are significantly different by Tukey's test at a probability level of $1 \%$. Relative inhibition (RI) was calculated by the following formula: RI $(\%)=[($ Radial growth in control Radial growth in samples)/Radial growth in control] x 100. 


\section{ACKNOWLEDGMENTS}

The authors thank Conselho Nacional de Desenvolvimento Científico e Tecnológico (CNPq), Coordenação de Aperfeiçoamento de Pessoal de Nível Superior (Capes), Fundação de Amparo à Pesquisa do Estado do Pará (FAPESPA), Universidade Federal Rural da Amazônia (UFRA), and Universidade Federal do Pará (UFPA), Brazil.

\section{REFERENCES}

Adams PD and Kloepper JW (2002). Effect of host genotype on indigenous bacterial endophytes of cotton (Gossypium hirsutum L.). Plant Soil. 240: 181-189.

Albuquerque FC and Ferraz S (1976). Características morfológicas e fisiológicas de Nectria haematococca f. sp. piperis e sua patogenicidade à pimenta do reino (Piper nigrum L.). Experientia 22: 133-151.

Albuquerque FC, Duarte MLR, Benchimol RL and Endo T (2001). Resistência de piperáceas nativas da Amazônia à infecção causada por Nectria haematococca f. sp. piperis. Acta Amaz. 31: 341-348.

Altschul SF, Gish W, Miller W, Myers, et al. (1990). Basic local alignment search tool. J. Mol. Biol. 215: 403-410.

Anith KN, Radhakrishnan NV and Manomohandas TP (2003). Screening of antagonistic bacteria for biological control of nursery wilt of black pepper (Piper nigrum L.). Microbiol. Res. 158: 91-97.

Aravind R, Kumar A, Eapen SJ and Ramana KV (2009). Endophytic bacterial flora in root and stem tissues of black pepper (Piper nigrum L.) Genotype: isolation, identification and evaluation against Phytophthora capsici. Lett. Appl. Microbiol. 48: 58-64.

Benchimol RL, Chu EY, Muto RY and Dias-Filho MB (2000). Controle da fusariose em plantas de pimenta-do-reino com bactérias endofíticas. Pesq. Agropec. Bras. 35: 1343-1348.

Chen C, Bauske EM, Musson G, Rodriguez-Kabana R, et al. (1995). Biological control of Fusarium wilt on cotton by use of endophytic bacteria. Biol. Control. 5: 83-91.

Cho KM, Hong SY, Lee SM, Kim YH, et al. (2007). Endophytic bacterial communities in ginseng and their antifungal activity against pathogens. Microb. Ecol. 54: 341-351.

Cruz LM, Souza EM, Weber OB, Baldani JI, et al. (2001). 16S Ribosomal DNA characterization of nitrogen-fixing bacteria isolated from banana (Musa spp.) and pineapple (Ananas comosus (L.) Merril). Appl. Environ. Microbiol. 67: 2375-2379.

Fey PD and Olson ME (2010). Current concepts in biofilm formation of Staphylococcus epidermidis. Future Microbiol. 5: $917-933$.

Glick BR (2012). Plant growth-promoting bacteria: mechanisms and applications. Scientifica 2012: 963401.

Granér G, Persson P, Meijer J and Alström S (2003). A study on microbial diversity in different cultivars of Brassica napus in relation to its wilt pathogen, Verticillium longisporum. FEMS Microbiol. Lett. 224: 269-276.

Hassan MN, Afghan S and Hafeeza FY (2011). Biological control of red rot in sugarcane by native pyoluteorin-producing Pseudomonas putida strain NH-50 under field conditions and its potential modes of action. Pest Manag. Sci. 67: 1147-1154.

Hsieh TF, Huang HC and Erikson RS (2005). Biological control of bacterial wilt of bean using a bacterial endophyte, Pantoea agglomerans. J. Phytopathol. 153: 608-614.

Huang CJ, Wang TK, Chung SC and Chen CY (2005). Identification of an antifungal chitinase from a potential biocontrol agent, Bacillus cereus 28-9. J. Biochem. Mol. Biol. 38: 82-88.

IBGE (2014). Levantamento Sistemático da Produção Agrícola. IBGE 27: 1-85. Available at [http://www.ibge.gov.br/ home/estatistica/indicadores/agropecuaria/lspa/default_publ_completa.shtm]. Accessed October 9, 2014.

Islam SMA, Math RK, Kim JM, Yun MG, et al. (2010). Effect of plant age on endophytic bacterial diversity of balloon flower (Platycodon grandiflorum) root and their antimicrobial activities. Curr. Microbiol. 61: 346-356.

Jaramillo MA and Manos PS (2001). Phylogeny and patterns of floral diversity in the genus Piper (Piperaceae). Am. J. Bot. 88: 706-716.

Kang SH, Cho HS, Cheong H, Ryu CM, et al. (2007). Two bacterial endophytes eliciting both plant growth promotion and plant defense on pepper (Capsicum annuит L.). J. Microbiol. Biotechnol. 17: 96-103.

Kanvinde L and Sastry GR (1990). Agrobacterium tumefaciens is a diazotrophic bacterium. Appl. Environ. Microbiol. 56: 2087-2092.

Liu XG, Gao KX, Kang ZS and He BL (2007). Systemic resistance induced by biocontrol agents in plants and its biochemical and cytological mechanisms. Ying Yong Sheng Tai Xue Bao. 18: 1861-1868. 
Mercado-Blanco J and Lugtenberg BJJ (2014). Biotechnological applications of bacterial endophytes. Curr. Biotech. 3: $60-75$.

Nascimento SB, Cascardo JC, Menezes IC, Duarte Mde L, et al. (2009). Identifying sequences potentially related to resistance response of Piper tuberculatum to Fusarium solani f. sp. piperis by suppression subtractive hybridization. Protein Pept. Lett. 16: 1429-1434.

Schenk ST, Hernández-Reyes C, Samans B, Stein E, et al. (2014). N-acyl-homoserine lactone primes plants for cell wall reinforcement and induces resistance to bacterial pathogens via the salicylic acid/oxylipin pathway. Plant Cell 26: $2708-2723$.

Selvakumar G, Mohan M, Kundu S, Gupta AD, et al. (2008). Cold tolerance and plant growth promotion potential of Serratia marcescens strain SRM (MTCC 8708) isolated from flowers of summer squash (Cucurbita pepo). Lett. Appl. Microbiol. 46: 171-175.

Silo-Suh LA, Lethbridge BJ, Raffel SJ, He H, et al. (1994). Biological activities of two fungistatic antibiotics produced by Bacillus cereus UW85. Appl. Environ. Microbiol. 60: 2023-2030.

Singh AK, Ghodke I and Chhatpar HS (2009). Pesticide tolerance of Paenibacillus sp. D1 and its chitinase. J. Environ. Manag. 91: 358-362.

Soltis PS, Soltis DE and Chase MW (1999). Angiosperm phylogeny inferred from multiple genes as a tool for comparative biology. Nature 402: 402-404.

Talebi MB, Bahar M, Saeidi G, Mengoni A, et al. (2008). Diversity of Sinorhizobium strains nodulating Medicago sativa from different Iranian regions. FEMS Microbiol. Lett. 288: 40-46.

Tamura K, Peterson D, Peterson N, Stecher G, et al. (2011). MEGA5: molecular evolutionary genetics analysis using maximum likelihood, evolutionary distance, and maximum parsimony methods. Mol. Biol. Evol. 28: 2731-2739.

Tran H, Kruijt M and Raaijmakers JM (2008). Diversity and activity of biosurfactant-producing Pseudomonas in the rhizosphere of black pepper in Vietnam. J. Appl. Microbiol. 104: 839-851.

Tripura C, Sashidhar B and Podile AR (2007). Ethyl methanesulphonate mutagenesis enhanced mineral phosphate solubilization by groundnut-associated Serratia marcescens GPS-5. Curr. Microbiol. 54: 79-84.

Trivedi P, Spann T and Wang N (2011). Isolation and characterization of beneficial bacteria associated with citrus roots in Florida. Microb. Ecol. 62: 324-336.

Valverde A, Igual JM, Peix A, Cervantes E, et al. (2006). Rhizobium lusitanum sp. nov. a bacterium that nodulates Phaseolus vulgaris. Int. J. Syst. Evol. Microbiol. 56: 2631-2637.

van Loon LC, Bakker PA and Pieterse CM (1998). Systemic resistance induced by rhizosphere bacteria. Annu. Rev. Phytopathol. 36: 453-483.

Vanitha S and Ramjegathesh R (2014). Bio Control Potential of Pseudomonas fluorescens against Coleus Root Rot Disease. J. Plant Pathol. Microb. 5: 216.

Vega FE, Pava-Ripoll M, Posada F and Buyer JS (2005). Endophytic bacteria in Coffea arabica L. J. Basic Microbiol. 45: 371-380.

Verhagen BW, Trotel-Aziz P, Couderchet M, Höfte M, et al. (2010). Pseudomonas spp.-induced systemic resistance to Botrytis cinerea is associated with induction and priming of defence responses in grapevine. J. Exp. Bot. 61: 249-260. 